\title{
Chapter 2 \\ Ecological Indicators for Surface Water \\ Quality - Methodological Approaches \\ to Fish Community Assessments in China and Germany
}

\author{
Sebastian Beggel, Joachim Pander, and Jürgen Geist
}

\subsection{Introduction}

This chapter provides an overview about the implemented water quality assessment regulations and methods with a special focus on Germany and China. In the first part, the general situation and the currently used ecological indicators are presented. In the second part, we exemplarily discuss the fish community assessment by different methodological approaches. Specifically active and passive fishing techniques are compared, which both, single or in combination, are used in Chinese or European fish monitoring surveys.

\subsubsection{The Need for Ecosystem Health Assessment}

Human activities and consequently the impact on freshwater ecosystems has increased significantly within the past decades, resulting in an unneglectable decline in biodiversity and ecosystem integrity worldwide [13]. As a matter of fact, aquatic habitats associated with $65 \%$ of continental discharge have been recently classified as moderately to highly threatened [52, 60, 61], which demonstrates that aquatic ecosystems have become highly dysfunctional due to high anthropogenic pressure. As summarized by Maloney [35], there has been a $81 \%$ global decrease in freshwater

\footnotetext{
S. Beggel $(\varangle) \cdot$ J. Pander $\cdot$ J. Geist

Aquatic Systems Biology Unit, TUM School of Life Sciences, Technical University of Munich, Mühlenweg 22, 85354 Freising, Germany

e-mail: sebastian.beggel@tum.de

J. Pander

e-mail: joachim.pander@tum.de

J. Geist

e-mail: geist@tum.de
} 
vertebrate populations over the last 30 years (see also [36]) and an average of $60 \%$ of protected species and $77 \%$ of habitat types are considered to be in unfavourable conservation status in Europe, with an even higher proportion in rivers, lakes and wetlands [19]. Furthermore, as the human population grows, human contact with and impacts on aquatic ecosystems increase. At present, more than $50 \%$ of the human population lives within $3 \mathrm{~km}$ of a freshwater system [26]. This has raised concerns over the impacts of anthropogenic activities on aquatic environments [59]. During the past centuries, the requirements for human economic development were often prioritized, sometimes neglecting negative impacts of human activities on aquatic ecosystems and the services they provide. Progress to align both, development and protection of freshwater resources was made during the last decades and the urgent necessity to preserve and restore a good ecological status of aquatic habitats has been recognized [19]. Various monitoring programs to determine water quality status and need for action were developed and implemented worldwide, with the USA and also European countries such as Germany. Recently, countries with a rapid economic development, such as China, are increasingly implementing monitoring tools for ecosystem health status assessment for environmental protection and to preserve biodiversity.

\subsubsection{Current Situation in China and Germany}

China's rapid economic and social development during the last decades resulted in increasing anthropogenic pressure on freshwater resources. Therefore already in the 11th Five Years Plan (2006-2010) China consistently improved its measures to control pollution and protect the environment within their major watersheds. Major threats to aquatic ecosystems in China are mainly caused by large scale hydromorphological modifications, water scarcity and severe water pollution from industrial, agricultural and municipal emissions. According to the 2017 Report on the State of the Ecology and Environment in China, 23.8\% of 1,940 monitored surface water sections were rated with grade IV and V -utilizable for industry, agriculture and recreation without skin contact only- whereas $8.3 \%$ did not meet grade V standards -not suitable for human contact or any use- (Table 2.1; [38]). As a developmental goal it was legally implemented in China to improve surface water quality until 2020, with less than $5 \%$ classified as grade $\mathrm{V}$ or worse, and more than $70 \%$ shall meet grade III or better [42].

Historically, European countries such as Germany had a long history of water management and protection. European countries were facing similar environmental problems during their rapid economic development in the $20^{\text {th }}$ century. In the $1970 \mathrm{~s}$, when those countries' surface waters were highly polluted, measures were implemented to improve the environmental conditions sustainably, e.g. by improving waste water treatment and regulating emissions into surface waters. A Europe-wide approach was finally implemented in 2000 by the European Union, the EU Water Framework Directive (WFD) [16], where the good ecological status or potential 
Table 2.1 Chinese water quality grades and respective water uses (Source: [38])

\begin{tabular}{l|l}
\hline Grade & Use \\
\hline I-II & $\begin{array}{l}\text { First-class protection zones for drinking water resources; habitats of rare aquatic } \\
\text { species; fish and shrimp spawning grounds }\end{array}$ \\
\hline III & $\begin{array}{l}\text { Second-class protection zones for drinking water resources; fish and shrimp } \\
\text { overwintering ground; migration channels; aquaculture areas; swimming sites }\end{array}$ \\
\hline IV & Industrial use; recreational purpose (without skin contact) \\
\hline V & Irrigation (agri-/horticulture, landscape) \\
\hline $\mathrm{V}+$ & Hardly any function except regulating local climate \\
\hline
\end{tabular}

for surface water bodies was defined as overall goal to be reached by the year 2015 . Nevertheless, European countries have largely failed to reach the initial goals in water quality status of surface waters by today. Only $7.7 \%$ of Germany's rivers reached the European Water Framework Directive's binding environmental objective of good ecological and chemical status by 2015 . 34.4\% of the 8,995 monitored sites exhibited a poor ecological status-major deviations from surface water body type-specific values of biological quality elements and biological communities. Further 19.9\% were classified as bad-severe alterations to surface water body, type-specific values of biological quality elements and absence or strong degradation of the ecological integer biological communities.

While Germany utilizes biological, hydromorphological and physico-chemical metrics to determine water quality since the early nineties of the last century, China's water monitoring is predominantly based on physico-chemical variables using a dense net of automated monitoring stations covering the main river basins. Those analyses are the most direct approach to define chemical water quality, but on the other hand they are of limited use to allow predictions about aquatic organisms' responses to pollution nor pollution-related influences on ecosystem level [50]. Biological monitoring can provide insights into the organism-habitat relationship by means of indicator species. The presence or absence of such species enables the detection of pollution and the evaluation of biological threats to ecosystem health [23]. Since aquatic organisms cope with chemical, physical and biological habitat alterations over their entire lifecycle, they additionally allow identification of the longterm ecological status of environments. Furthermore, steep pollution and disturbance gradients are appropriately determined by biological data [21]. Acknowledging the relevance of ecological methodologies for water quality assessment, China launched a pilot national monitoring program to assess ecological integrity in 2010.

\subsubsection{Ecological Indicators of Ecosystem Integrity}

The biological integrity of freshwater ecosystems, here river or lotic systems, is typically considered by separately assessing so-called biological quality elements (QEs) 
such as fish, macroinvertebrates, macrophytes and algae. In combination these quality elements are used to create a comprehensive picture of the current status of the respective system with the component of the worst assessment determining the status class (one-out-all-out principle). Each of these biological groups can be utilized to derive structural indicators according to their presence or absence in the assessed ecosystem [45]. This allows to draw conclusions about the systems current condition, e.g. good, bad or poor, and additionally facilitates the comparison of the current status with past and future conditions for monitoring purposes. Structural indicators are used to determine ecosystem integrity and allow to draw conclusions about the stability of the ecosystem, e.g. the capacity of an ecosystem to maintain its organization, in rivers mostly linked to river dynamic processes such as sediment relocation or deadwood dynamics. From a scientific point of view, most commonly used indicators are, for example, species richness and diversity, characteristic species assemblage or trophic structure [35]. For monitoring purposes these attributes are especially useful since their assessment can be realized by point-in-time measurements within the respective habitats [43]. Diversity for instance is measured by sampling organisms from a specific community (e.g., fish, aquatic invertebrates, macrophytes) and considering the number of unique taxonomic groups and the number of organisms per group. By applying a standardized sampling design following pre-determined methodological protocols a spatial and temporal comparability is warranted. In river ecosystem assessment, the fish species diversity at a representative site is a structural metric that reflects ecosystem integrity and availability of typical habitats as well as habitat connectivity. Variations in diversity are identified by comparing the current abundance and density of aquatic species in an ecosystem with that of a reference site or historical ecosystem state. Furthermore, this metric can be used to determine potential risks to ecosystem integrity if significant changes in biological structure are detected or specific taxa are missing [31], or on the contrary to measure restoration success [45]. Other commonly used structural metrics include biomass, species richness or dominance or presence or absence of indicator species. Hydromorphological and water physico-chemical criteria are additionally used to aid the biological metrics.

\subsubsection{Biological River Assessment Approaches Applied in China and Germany}

Legal and institutional frameworks as described in the previous Chapter 1 highlight that management, protocols, analyses and reports of river monitoring results vary between states, commissions, districts and municipalities. Therefore, the comparison of quality elements (QEs) used in river assessments in Germany and China is based on surveys carried out nation-wide. This includes China's Environmental Quality Standards for Surface Water [39] and river monitoring under the WFD in Germany. 


\subsubsection{China}

China's rivers are assessed according to the national Environmental Quality Standards for Surface Water [39]. This standard lists 109 chemical and physical parameters of which 24 are classified as basic parameters, five as supplementary parameters, and 80 as specific parameters. Basic parameters are implemented for rivers, lakes, channels, and reservoirs, whereas supplementary and specific parameters are applied to drinking water resources. The standard's basic parameters comprise heavy metals, nutrients, water temperature, $\mathrm{pH}$ value, dissolved oxygen, chemical oxygen demand (COD), and biochemical oxygen demand (BOD). For each of the basic parameters, the standard sets thresholds, pursuant to the standard's surface water quality grades (Table 2.1). The grade is attributed on basis of the one-out-all-out principle. Thus, the worst grade attained by any considered parameter represents the final water quality grade. Grade I and II are generally in agreement with the WHO-Drinking Water Guideline values and most recent Chinese Drinking Water Standards [18]. The standard further provides general guidelines pertinent to monitoring procedures and mandate local WRABs to implement and supervise its adaption.

The research process on river health in China was initiated in 1992, when [67] described water quality of Jiuhua River using the Ephemeroptera, Trichoptera, Plecoptera (EPT) and the Family Biotic Index (FBI). Since the early 2000s, researchers in China $[62,63,70]$ started to focus on urban river health assessments in relation to China's fast urbanization process. Furthermore, the administrative agencies responsible for the Yellow River, Yangtze River and Pearl River Basin suggested concepts to promote river health [22,30,69]. Broader studies on the ecological status and water quality of rivers based on macroinvertebrates were conducted and pilot schemes for monitoring and assessment of those were implemented. These include, amongst others, [28, 44] and [64]. Evidently, the biological assessment of rivers is gradually brought to attention of Chinese river management. Up until the year 2019, no nation-wide assessment program exists, but this is supposed to be changed in the future. The utilized structural metrics for biological quality elements, currently applied mainly for academic purposes, include aquatic macroinvertebrates, fish and benthic algae. For macroinvertebrates the calculation of "family richness", "macroinvertebrate BMWP score" and "EPT family richness" is used. For fish communities the "fish species index", "fish biotic index" and "fish Berger Parker index" are used and for benthic algae the "algal biotic index" and "algal Berger Parker index".

\subsubsection{Germany}

For several years, Germany has been monitoring its running waters according to the demands of the WFD, requiring the assessment of QEs as described below. Hydromorphological and physico-chemical QEs support biological QEs, but cannot replace them. The river status class (Table 2.2) is obtained from a ratio, which represents the relationship between the values of biological parameters observed for a given stream or river and the values of these parameters in the undisturbed reference condition 
Table 2.2 General definition of rivers' ecological quality in Germany (adapted from: EC 2000)

\begin{tabular}{l|l}
\hline Status & Normative definition \\
\hline High & $\begin{array}{l}\text { Physico-chemical/hydromorphological quality elements } \\
\text { No, or only very minor, anthropogenic alterations to river type-specific } \\
\text { undisturbed reference conditions } \\
\text { Biological quality elements } \\
\text { Values reflect river type-specific undisturbed reference conditions, and show no, } \\
\text { or only very minor, evidence of distortion; river type-specific conditions and } \\
\text { communities }\end{array}$ \\
\hline Good & $\begin{array}{l}\text { Biological quality elements } \\
\text { Low levels of distortion resulting from human activity are evident, but deviate } \\
\text { only slightly river type-specific undisturbed conditions }\end{array}$ \\
\hline Moderate & $\begin{array}{l}\text { Biological quality elements } \\
\text { Moderate deviations from river type-specific undisturbed reference conditions; } \\
\text { moderate signs of distortion resulting from human activity; significantly more } \\
\text { disturbed than under good status condition }\end{array}$ \\
\hline Poor & $\begin{array}{l}\text { Biological quality elements } \\
\text { Major deviations from river type-specific undisturbed reference conditions; } \\
\text { relevant biological communities deviate substantially from those of river-type } \\
\text { specific undisturbed reference conditions }\end{array}$ \\
\hline Bad & $\begin{array}{l}\text { Biological quality elements } \\
\text { Severe alterations from river type-specific undisturbed reference conditions; } \\
\text { absence of large proportions of relevant biological communities of river-type } \\
\text { specific undisturbed reference conditions }\end{array}$ \\
\hline
\end{tabular}

pursuant to the river or stream type. Reference conditions have been defined for 25 stream and river types [51]: four types for the eco-region of the Alps and Alpine foothills, eight types for the Central German Highlands, nine types for the North German Lowlands and four ecoregion-independent types. The worst assessment result of a biological QE determines the overall assessment result (one-out-all-out principle).

Aquatic macroinvertebrates are indicators of local environmental conditions. Since 1991, the method of assessing water quality and the organic impact in running waters based on macroinvertebrates has been regulated by the German standard DIN 38410 [8]. It is based on one of the traditional saprobic procedures [47]. Samples are taken accordingly to the international standard DIN-EN-ISO 10870 [9]. Calculation, classification and presentation are also standardized. The ecological status can be determined with the assessment system PERLODES [37]. More detailed information for the asessment of running waters using macroinvertebrates as passive indicators is given in [23].

The analysis of macrophytes is a particularly well-suited tool for monitoring long-term trends in trophic conditions [53]. Nationally, the multi-habitat-sampling of macrophytes follows a standardized protocol. Besides coverage, vitality, and sociability of each species, environmental data such as shading, flow velocity, average water depths and substrate type are recorded. In Germany, the assessment of the 
subcomponent macrophytes is enabled by the assessment system PHYLIB [2]. Alternatively, the NRW-procedure [57] can be used for the assessment of rivers based on macrophytes. Both assessment methods define states of potentially natural vegetation by means of a community approach. The determination of river water quality stems from the occurrence of non-typical vegetation units. PHYLIB is also applied to the subcomponent phytobenthos. Sampling and microscopy follow standardized protocols. During sampling, species coverage and substrate types are recorded. The microscopy protocol requires the determination of taxonomic unit and each unit's frequency of occurrence.

The establishment of a nationwide classification and assessment system of streams using phytoplankton was firstly initiated by the adoption of the WFD. Standardized methods for sampling, handling of samples, and analysis are described in the manual by [40]. It is restricted to medium-sized and major rivers. For the assessment of plankton-dominated streams, the software PhytoFluss is available.

Fish are sensitive to modifications of river morphology and lateral as well as longitudinal river channel connectivity. The survey of fish population characteristics is performed by electrofishing. Six QEs are standardized recorded: species and guilds inventory, species abundance and guilds distribution, age structure, migration (indexbased), fish region (index-based), and dominant species (index-based). Those QEs (metrics) are compared to a priori defined river-type reference fish biocenosis which is based on expert knowledge. Depending on the deviation of observed values of QEs from values of the reference, scores are achieved. The average score determines the status classification. The methodology in Germany is based on [15]. The assessment of the subcomponent fish is performed by application of the assessment system fiBS [14].

In contrast to biological elements, hydro-morphological QEs are not primarily decisive for assessing the status of a river, but are determining the distribution as well as habitat heterogeneity, availability and niches for biotic communities. Hydromorphological QEs of the WFD are morphology, hydrological regime and continuity. The quality element morphology does not only focus on the riverbed (course development, longitudinal profile, bed structure), but also on the banks (cross-section, bank profile) and the floodplain [6]. Rivers are assigned to five structural classes. The allocation to the classes is based on the extent by which a river's morphology deviates from river-type-specific reference condition. A river's hydrology is classified using the parameters connection to groundwater bodies, discharge, and discharge dynamics. On the basis of data and expert knowledge, the intensity of given pressures, such as water abstractions or engineering measures, are related to the potential natural status. The classification into five classes (Table 2.2) is based on the one-outall-out principle [7]. The procedure is currently undergoing practical trials [20]. A method to classify the continuity of watercourses is being developed by LAWA [20].

According to Annex V of the WFD, five physico-chemical quality elements of running waters need to be monitored: visibility, temperature, oxygen, conductivity, acidification, and nutrient conditions. Water body type-specific background values (very good status) and threshold values (good status/good ecological potential) are listed in Annex 7 to the Ordinance on Surface Waters. Measured values determine 
the allocation to quality classes. High status is achieved if measured values adhere to river-type-specific background values. If measured values are within a range which guarantees river-type-specific correct functioning, a good status is achieved.

\subsection{Methodological Comparison of Fish Community Assessment}

As described previously, there are several advantages when biological metrics are complementary considered in surface water health assessment and monitoring. Since fish assemblages are considered to be a highly suitable metric for assessing river health $[1,24,25]$, there are ongoing activities in China, predominantly on the academic level, to further develop and adjust fish-based indices for Chinese surface waters. Example applications in China using the "index of biological integrity" (IBI) for river health assessment were reported for the Yangtze River [33], the Liao River [48], and some local small rivers [22, 32]. Structural metrics such as the IBI demand a predetermined sampling strategy and the proper choice of methods to be applied. The choice of efficient sampling techniques is thereby a crucial factor for the success of sampling strategies [5, 41, 45].

The following section of this chapter provides a methodological comparison of fish communities along a $70 \mathrm{~km}$ stretch of the Fan River, Lioaning province in China. Specific objectives are the comparison of (i) Active vs. Passive sampling methods, (ii) German vs. Chinese sampling approach and techniques, (iii) Determination of fishing technique effectivity for overall community characterization.

\subsubsection{Methodology}

\subsubsection{Choice of Sampling Methods}

In contrast to less mobile organisms such as plants and some macroinvertebrates, the assessment of fish communities relies on efficient and non-selective sampling techniques $[4,5]$. Since fishing techniques are applied from the early development of human societies on, there is a great variety of different active and passive fishing methods. Today applied standardized methods include electrofishing [27, 41, 49], hook-and-line methods, net-based methods and the use of traps [4, 5, 34, 46, 68]. Catch rates, selectivity patterns and species specificity may differ strongly, however, depending on the sampling method chosen. Thus, an accurate characterization of populations can be difficult [11]. Additionally, the efficiency of the respective fishing method most likely varies with the change of stream size as well as turbidity, current velocity and conductivity [24, 41, 54]. Assessment methods currently applied in 
China comprise electrofishing for wadeable [22] or gill-netting for non-wadeable streams [17], as well as casting nets and seining [29]. Standardization of assessment is often not reported or impossible when investigations include catches from local fishermen [29].

\subsubsection{Area of Experimental Investigation}

For the methodological comparison, 6 characteristic sites within the Fan River were chosen together with the Chinese project partners (N 42.10826, E 12.448.517 - N 42.257.50, E 12.360.941). The selection of the sampling area was based on the bilateral workshops held between the German and Chinese partners of the SINOWATER project at the Chair of Aquatic Systems Biology in Freising, Germany in 2016. The Fan River is a tributary to the Liao River, one of the seven major river basins in China. Fan River is a well suited model stream, since within less than $100 \mathrm{~km}$ the headwater region and the confluent to the Liao River main stem can be reached. The sampling area covers a gradient from wadeable sections with low-flow conditions at the most upstream site to non-wadeable conditions at the confluent and an elevation gradient from 51 to $370 \mathrm{~m}$ above sea level (upper sites dominated by agriculture in the catchment, lower sites with influence of the city of Tieling and water abstraction for irrigation + large reservoir in-between). Site ID and pictures are given in Table 2.3. Sites 3-6 are characterized by a major increased discharge from Zhenziling Reservoir above site 3.

\subsubsection{Description of Sampling Methods and Design}

Herein three active and three passive methods were used for fish community assessment. The survey was conducted in May 2017, at this time of the year typically no extreme flood or drought events occur, which would have hampered sampling activities. Active methods comprised single-pass electrofishing as typically applied in Germany and China as well as seining. As passive methods common minnow traps were used as well as gill-netting and longline-fishing. Specifications of the respective methods are listed in Table 2.4.

The sampling design used in this investigation allowed to simultaneously apply the different fishing methodologies within the same section of the river, including replication of each of the methods and coverage of structural variation. Sampling sections were chosen to represent a wide range of environmental conditions from fastflowing upstream sections to slow-flowing downstream sections. At each sampling site, a $500 \mathrm{~m}$ stretch was selected and divided into three main replicate sections of $150 \mathrm{~m}$ each, Within these $150 \mathrm{~m}$ sections, there were $30 \mathrm{~m}$ assigned for each of the active methods (electrofishing German (EG), electrofishing China (EC) and seining $(\mathrm{SN})$ ). Passive fishing methods, longline-fishing (L) and traps (T) were spaced 
Table 2.3 Sampling sections for the methodological comparison in Fan River, Liaoning province, China

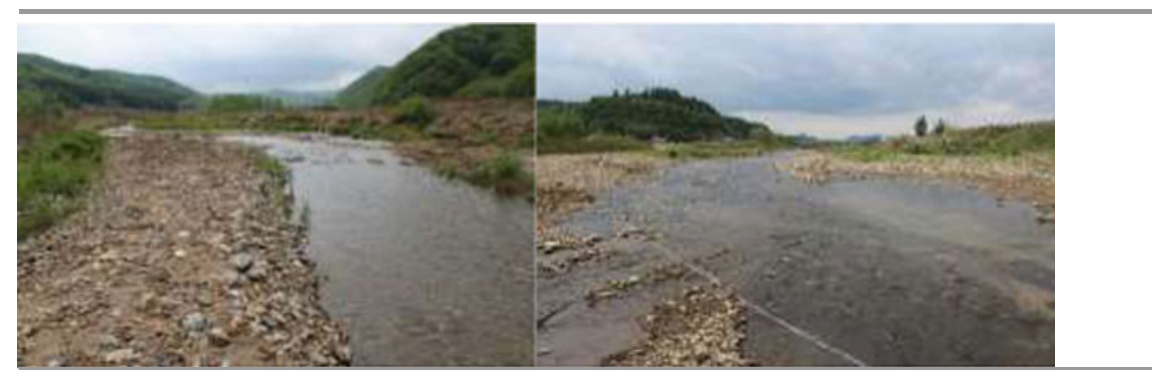

Sitete 1 - JiaHeChang

Site 2 - BaiQiZhai

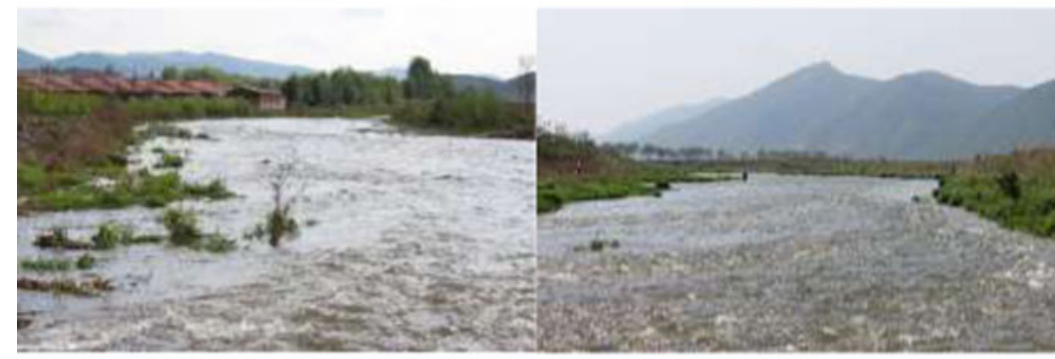

Site 3 - XiaoTun

Site 4 - LaoBianTai

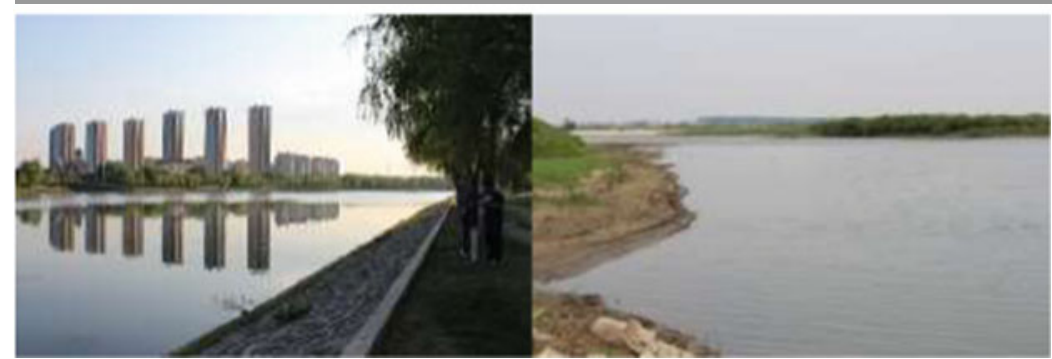

Site 5 - FanheBridge (City of Tieling)

Site 6 - HuangHeZi

in between the active fishing sections as well as at the most upstream and most downstream end of the whole sampling site resulting in 5 replicates per method. Gillnetting was only applicable at the most downstream site 6 . A graphical representation of the sampling design is given in Fig. 2.1. At the most upstream part a $50 \mathrm{~m}$ section for time-based electrofishing was located. For each specimen, the total length (TL) was measured to the nearest $0.1 \mathrm{~cm}$, total weight (WT) was measured with $1 \mathrm{~g}$ accuracy on a representative subsample of fish. 
Table 2.4 Specification of applied active and passive fishing methods

\begin{tabular}{ll}
\hline Method type & Specification \\
\hline Active & \\
$\begin{array}{l}\text { Electrofishing Ger- } \\
\text { man (EG) }\end{array}$ & $\begin{array}{l}\text { Graß1 ELT62, } 3 \mathrm{~kW}(300 \mathrm{~V}) \text { engine-powered } \\
\text { backpack-electrofisher connected to } 1 \\
\text { handheld anode with a 30cm dipnet and a } \\
\text { passive braided wire copper cathode. Fish } \\
\text { were collected by an assistant person with a } \\
\text { dipnet and transferred to a bucket. }\end{array}$
\end{tabular}

Electrofishing Chi- Two copper electrodes on telescope handles, nese (EC) one equipped with a $20 \mathrm{~cm}$ dipnet, powered by a $24 \mathrm{~V}$ battery. Fish were collected by the operator and collected by a second person carrying a bucket.

Electrofishing Chi- Same equipment as EC. Sampling was connese - time based (EC30) ducted by fishing a zigzag route across the sampling section for 30 minutes.
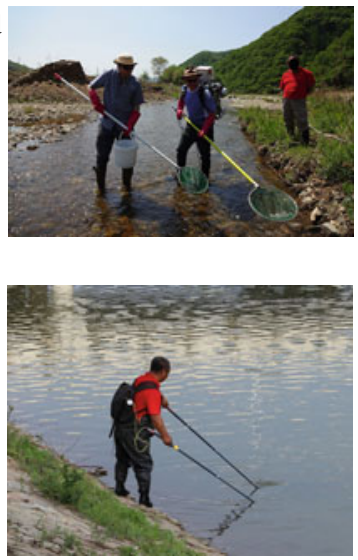

Seining

$15 \mathrm{~m}$ net, mesh-size $10 \mathrm{~mm}$, lead-bottomline. Spreading of the net in $90^{\circ}$ angle to the river bank towards the middle of the river, then pushing the net back in a half-cirlce towards the bank

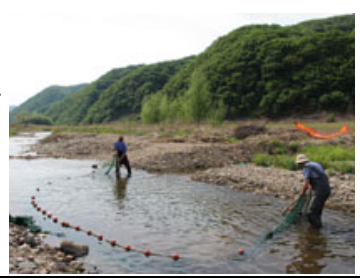

\section{Passive}

Trapping (T)

Minnow trap, diameter $30 \mathrm{~cm}$, length $60 \mathrm{~cm}$. Commercial cat-food used as bait. Placed in deeper sections with the whole trap being submerged.

Longline (L)

$5 \mathrm{~m}$ fishing line - 3 types barbed hooks (\#1, \#6, \#10) replicated 5 times. Each hook size was equipped with different bait: fish filet, mussel meat or worms, and maggot.

Gillnet

$20 \mathrm{~m}$ long, $1 \mathrm{~m}$ wide, $2 \mathrm{~cm}$ mesh. Brought into a stagnant deep area by boat.
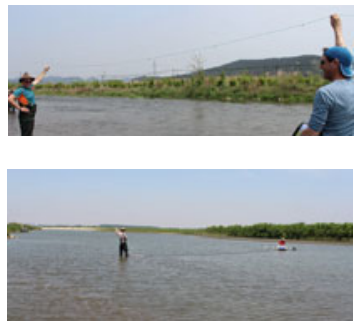


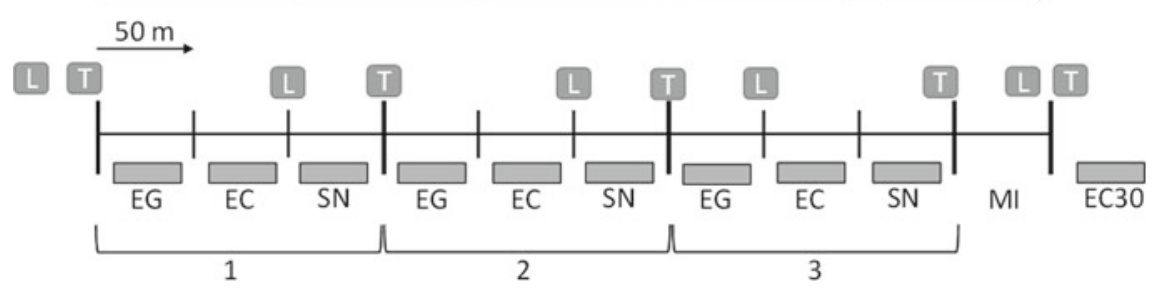

Fig. 2.1 Schematic representation of the sampling design applied. EG: Electrofishing German, EC: Electrofishing China, EC30: 30 min Electrofishing china, SN: Seining, L: Longline fishing, T: Trapping, 1-3: replicate sections, MI: additional zone for macroinvertebrate sampling

\subsubsection{Calculated Metrics}

For comparison of the method-dependent catch, the following metrics are reported: Species abundance, Species richness (d), Shannon diversity index (H'), Eveness (J') Condition indices for each species (BMI), species biomass. To express the effectiveness of each method, the Catch per Unit Effort (CPUE) was calculated. For comparability the CPUE per $10 \mathrm{~min}$ is presented. Richness was calculated by counting all the taxa for each site, specific calculations are given below.

$$
H=-\sum_{i=1}^{S} P_{i} \log _{2} P i
$$

where $\mathrm{S}$ is the total number of taxa, $\mathrm{Pi}$ is the relative abundance of species $\mathrm{i}$.

$$
B M I=\frac{\left(W_{T} \times 100\right)}{L_{T}^{3}}
$$

WT: Total weight (nearest g); LT: Total length (nearest $0.1 \mathrm{~cm}$ ).

$$
C P U E=\frac{N_{i}}{t_{i}}
$$

$\mathrm{Ni}$ : Number of individuals per replicate section $\mathrm{i}$; ti: time of fishing at replicate section $\mathrm{i}$

$$
\begin{gathered}
d=\frac{S-1}{\log _{e} N} \\
J^{\prime}=\frac{H^{\prime}}{\log _{e} S} \\
1-\lambda^{\prime}=1-\frac{\left\{\sum i N i(N i-1)\right\}}{\{N(N-1)\}}
\end{gathered}
$$


S: Total number of taxa; N: Total number of individuals.

\subsubsection{Results}

\subsubsection{Fish Community}

A total of 33 fish species from 10 different families comprising 7799 specimen were collected by all methods (and sites) combined. Most of the sampling sites within the Fan River system showed to be dominated by Cyprinidae, comprising up to $85 \%$ of all fish specimen caught, followed by Nemacheilidae, Cobitidae and Gobiidae. The fish community was generally characterized by generalists like Rhynchocypris lagowskii, Barbatula nuda and Zacco platypus. These first two species represented $21.9 \%$ and $23.7 \%$ of the total fish biomass, respectively. They were found at every site except the most downstream site 6, HuangHeZi, where the fish assemblage was dominated by Carassius auratus and Abbottina rivularis, most likely due to the vicinity of the Liao River main stem. In general, no apex predators or fish larger $16 \mathrm{~cm}$ (total length) were caught by the methods applied or are simply missing in Fan River. A full list of the Fan River fish community is presented in Table 2.5. Cobitis granoei, Pseudorasbora parva and Zacco platypus were detected at all sites. Some species such as Aphyocypris chinensis (site 2), Chanodichthys erythropterus (site 6), Hypomesus olidus (site 6), Opsariichthys bidens (site 2), Romanogobio tenuicorpus (site 6) were only detected at single sites. In site 6 three of the species exclusively occurred, indicating a strong influence of the Liao River on the fish community.

For 9 species less than 10 individuals were found (Chanodichthys erythropterus, Gymnogobius urotaenia, Tachysurus fulvidraco, Hypomesus olidus, Pungitius sinensis, Misgurnus mohoity, Silurus asotus, Oryzias sinensis, Opsariichthys bidens).

In terms of metrics the German electrofishing method resulted in the highest value for $\alpha$-diversity with $H^{\prime}=2.35$ in contrast to seining (1.65), Table 2.6. The catch from trapping resulted in the highest values for species richness with $\mathrm{d}=3.936$.

\subsubsection{Method Efficiency}

In comparison of overall method efficiency, none of the methods turned out to be suitable to cover the full species range detected at each site compared to all methods combined. The electrofishing methods, however, detected always at least $>50 \%$ of the species, while seining detected less than $40 \%$. The results using the German electrofishing method (EG) had the greatest overall coverage in terms of number of taxa and biomass, and was suited to detect 56-100\% of the species present at the specific sites. This result is further corroborated by the comparison of the catch per unit effort (CPUE). The electrofishing methods in general was the most effective method to characterize fish assemblages. The calculated CPUE generally revealed 
Table 2.5 List of fish species in the Fan River system. Total number of individuals $(\mathrm{N})$, percentage of total catch (Proportion) and biomass is given

\begin{tabular}{|c|c|c|c|}
\hline Species name & Sum N & Proportion [\%] & Biomass [kg] \\
\hline $\begin{array}{l}\text { Rhynchocypris } \\
\text { lagowskii }\end{array}$ & 2484 & 31.8 & 4.56 \\
\hline Barbatula nuda & 1683 & 21.6 & 3.00 \\
\hline $\begin{array}{l}\text { Abbottina } \\
\text { rivularis }\end{array}$ & 481 & 6.17 & 1.49 \\
\hline Carassius auratus & 377 & 4.8 & 4.94 \\
\hline Cobitis granoei & 374 & 4.8 & 0.39 \\
\hline $\begin{array}{l}\text { Pseudorasbora } \\
\text { parva }\end{array}$ & 340 & 4.4 & 0.66 \\
\hline $\begin{array}{l}\text { Rhinogobius } \\
\text { giurinus }\end{array}$ & 337 & 4.3 & 0.52 \\
\hline $\begin{array}{l}\text { Misgurnus } \\
\text { anguillicaudatus }\end{array}$ & 298 & 3.8 & 0.58 \\
\hline $\begin{array}{l}\text { Rhinogobius } \\
\text { brunneus }\end{array}$ & 218 & 2.8 & 0.14 \\
\hline Zacco platypus & 195 & 2.5 & 0.52 \\
\hline $\begin{array}{l}\text { Rhinogobius } \\
\text { cliffordpopei }\end{array}$ & 194 & 2.5 & 0.22 \\
\hline Rhodeus lighti & 187 & 2.4 & 0.19 \\
\hline $\begin{array}{l}\text { Microphysogobio } \\
\text { chinssuensis }\end{array}$ & 164 & 2.1 & 0.27 \\
\hline $\begin{array}{l}\text { Gobio } \\
\text { cynocephalus }\end{array}$ & 107 & 1.4 & 0.31 \\
\hline $\begin{array}{l}\text { Acanthorhodeus } \\
\text { chankaensis }\end{array}$ & 91 & 1.2 & 0.22 \\
\hline $\begin{array}{l}\text { Micropercops } \\
\text { swinhonis }\end{array}$ & 60 & 0.8 & 0.10 \\
\hline $\begin{array}{l}\text { Paramisgurnus } \\
\text { dabryanus }\end{array}$ & 55 & 0.7 & 0.15 \\
\hline $\begin{array}{l}\text { Aphyocypris } \\
\text { chinensis }\end{array}$ & 29 & 0.4 & 0.05 \\
\hline $\begin{array}{l}\text { Romanogobio } \\
\text { tenuicorpus }\end{array}$ & 23 & 0.3 & 0.03 \\
\hline Rhodeus lighti & 21 & 0.3 & 0.02 \\
\hline $\begin{array}{l}\text { Hemiculter } \\
\text { leucisculus }\end{array}$ & 20 & 0.3 & 0.01 \\
\hline Lefua costata & 17 & 0.2 & 0.02 \\
\hline Oryzias sinensis & 9 & 0.1 & $<0.01$ \\
\hline $\begin{array}{l}\text { Opsariichthys } \\
\text { bidens }\end{array}$ & 9 & 0.1 & 0.44 \\
\hline Silurus asotus & 8 & 0.1 & 0.31 \\
\hline
\end{tabular}


Table 2.5 (continued)

\begin{tabular}{l|c|l|c}
\hline Species name & Sum N & Proportion [\%] & Biomass [kg] \\
\hline $\begin{array}{l}\text { Misgurnus } \\
\text { mohoity }\end{array}$ & 5 & $<0.1$ & 0.03 \\
\hline $\begin{array}{l}\text { Pungitius sinensis } \\
\text { Hypomesus olidus }\end{array}$ & 3 & $<0.1$ & $<0.01$ \\
\hline $\begin{array}{l}\text { Gymnogobius } \\
\text { urotaenia }\end{array}$ & 2 & $<0.1$ & $<0.01$ \\
\hline $\begin{array}{l}\text { Tachysurus } \\
\text { fulvidraco }\end{array}$ & 2 & $<0.1$ & $<0.01$ \\
\hline $\begin{array}{l}\text { Chanodichthys } \\
\text { erythropterus }\end{array}$ & 1 & $<0.1$ & 0.05 \\
\hline
\end{tabular}

Table 2.6 Diversity indices of fish community in Fan River based on the result of the different sampling methods

\begin{tabular}{l|l|l|l|l|l|l}
\hline Method & $\begin{array}{l}\text { Total species } \\
\text { S }\end{array}$ & $\begin{array}{l}\text { Total } \\
\text { individuals } \\
\text { N }\end{array}$ & $\begin{array}{l}\text { Species } \\
\text { richness } \\
\text { D }\end{array}$ & $\begin{array}{l}\text { Eveness } \\
\text { J' }\end{array}$ & $\begin{array}{l}\text { Shannon } \\
\text { diversity } \\
\text { H' }\end{array}$ & $\begin{array}{l}\text { Simpson } \\
\text { diversity } \\
\text { 1-Lambda }\end{array}$ \\
\hline EC & 24 & 1954 & 3.03 & 0.67 & 2.15 & 0.81 \\
\hline EC 30 & 27 & 1714 & 3.49 & 0.52 & 1.74 & 0.64 \\
\hline EG & 28 & 3570 & 3.30 & 0.70 & 2.35 & 0.84 \\
\hline SN & 11 & 125 & 2.07 & 0.69 & 1.65 & 0.69 \\
\hline T & 24 & 345 & 3.93 & 0.74 & 2.37 & 0.83 \\
\hline L & 0 & 0 & - & - & - & - \\
\hline
\end{tabular}

significant differences between all methods $(\mathrm{KW}, \mathrm{H}(3)=33.7, \mathrm{p}<0.001)^{1}$. Within the active methods, the seining resulted in a significant lower CPUE compared to electrofishing methods $(\mathrm{p}<0.05)$ and the passive method trapping showed significant lower CPUE compared to each other method $(\mathrm{p}<0.001)$. Seining indicated to be the least efficient method of the active methodologies, however still yielded a higher CPUE compared to passive methods. Longline fishing never yielded any catch, regardless the site in which this method was applied. The method efficiency comparison is presented in Table 2.7.

Gill-netting was not applicable in the upstream parts of the river with higher flowvelocities and shallow water depths. In the most downstream, deep and low flowing reaches, results from the gill-net differed in terms of species composition from all the other methods applied, presumably caused by being more selective towards pelagic species such as Carassius auratus or Hypomesus olidus which were hardly caught with the active fishing methods applied from the river bank as used in this comparison.

\footnotetext{
${ }^{1}$ Statistical comparisons to test for differences between groups were performed by using the Kruskal-Wallis rank-sum test, with Mann-Whitney U pairwise comparisons (Bonferroni corrected). Significance was accepted at $\mathrm{p}<0.05$.
} 
Table 2.7 Method efficiency comparison. Total number of taxa detected for each method and site. Values in brackets represent percentage of taxa detected in relation to total number of taxa by all methods combined

\begin{tabular}{l|l|l|l|l|l|l|l|l}
\hline Site & $\mathrm{N}$ species & $\mathrm{EC}$ & $\mathrm{EC}_{30}$ & $\mathrm{EG}$ & $\mathrm{G}$ & $\mathrm{L}$ & $\mathrm{SN}$ & $\mathrm{T}$ \\
\hline 1 & 9 & $5(56 \%)$ & $7(78 \%)$ & $5(56 \%)$ & N/A & 0 & $2(22 \%)$ & $2(22 \%)$ \\
\hline 2 & 19 & $15(79 \%)$ & $16(84 \%)$ & $16(84 \%)$ & N/A & 0 & $5(26 \%)$ & $10(53 \%)$ \\
\hline 3 & 15 & $13(87 \%)$ & $11(73 \%)$ & $15(100 \%)$ & N/A & 0 & $5(33 \%)$ & $11(73 \%)$ \\
\hline 4 & 16 & $11(69 \%)$ & $11(69 \%)$ & $13(81 \%)$ & N/A & 0 & $0(0 \%)$ & $10(63 \%)$ \\
\hline 5 & 19 & $10(53 \%)$ & $12(63 \%)$ & $17(89 \%)$ & N/A & 0 & $7(37 \%)$ & $9(47 \%)$ \\
\hline 6 & 21 & $9(42 \%)$ & $12(57 \%)$ & $15(71 \%)$ & $11(52 \%)$ & 0 & $5(24 \%)$ & $6(29 \%)$ \\
\hline
\end{tabular}

Some of the species that were only detected by method EG comprise bottom-dwelling species or "rare" species with overall specimen $<10$ at all sites combined.

\subsection{Discussion}

The results of this study highlight potential benefits of integrating standardized biological monitoring tools of fish community assessments that can be combined with existing Chinese standards for physico-chemical metrics used to rank surface water bodies into water quality grades I to $\mathrm{V}+$. The grading system stems from the perspective of water usage purposes, such as suitability for drinking or irrigation purposes. This is in contrast to the European system that primarily focusses on the alterations of the ecological status of its aquatic systems including the multiple impacts on them. With respect to the recent rapid economic development, impacts on aquatic ecosystems in China have heavily increased. In the year 2014 overall water quality did not meet the criteria for the general public and fishery use (at least Grade III) from $28.8 \%$ of the monitoring sections in major rivers [66]. In 2017, the physico-chemical water quality of rivers showed for $23.8 \%$ of the monitoring sections a quality grade IV and V, while $8.3 \%$ failed to meet the grade V standard [38]. Investigations by Chinese researchers have previously identified physical habitat alterations and chemical pollutants as key factors influencing fish communities in the Liao River Basin $[17,65]$. They also reported that, compared with the historical data, almost half of the fish species have disappeared and some local species were replaced by invasive ones. To meet the goal to restore biological integrity in the Liao River system and other watersheds in China, it becomes obvious that monitoring tools should consider biological quality elements such as fish. Since biomonitoring methods are already regionally tested, it can be anticipated that China's national assessment approach changes in the near future and suitable protocols will be developed soon. European monitoring programs (including Germany) comprise various types of quality elements. Biological water QEs are thereby primarily decisive for assessing a river's 
actual status. Physico-chemical and hydromorphological QEs support the biological QEs. Hereby, a large spectrum of the complexity of different biological and ecological characteristics as well as the large variety of pressures and impacts can be covered. One strength of this approach is the general comparability over space and time, which allows to detect deviations between the observed conditions and the respective reference conditions. Specific metrics, as applied in the European WFD cannot be used for a direct comparison here. For Chinese Rivers there is so far limited information on guilds distribution, migration (index-based), fish region (index-based), and dominant species (index-based) as used in Europe.

For a representative assessment not only the choice of methods is crucial, but also the consideration of site-specific characteristics [4, 5, 41]. Depending on present fish communities either passive or active bioindication methods [45] might be suitable, ideally comprising a combination of different methods. In the method comparison presented here, the differences between the applied sampling strategies could exemplarily be shown. However, no method was suitable to detect all the species present at a given site. Only a combination of active and passive sampling techniques provides a best-case coverage. Electrofishing-based methods showed to be most effective, regarding range, efficiency and the potential to detect rare species. In this direct comparison the German electrofishing method revealed to be more suitable in comparison to the other applied methods in terms of efficiency and CPUE. In general it can be stated that active methods such as electrofishing should preferentially be used for fish community assessment in running waters [10]. There were minor differences between the Chinese and the German electrofishing, however, most likely this is rather a function of the established voltage by the different power sources used. Ideally the power of the electrofishing gear is adequately chosen, based on the river-specific size, discharge, depth and conductivity [41]. This approach is already applied in European fish stock assessments like the European Water Framework directive monitoring programs [10]. For headwater areas and small wadeable rivers, the Chinese electrofishing gear proved to be sufficient to characterize the present fish community. However, when species richness (or age structure) is the target of the fish assessment, this method increases the risk of missing species (or size classes). Thereby the time-based approach EC30 provided a broader spectrum compared to the single-pass fishing approach. In contrast, the estimation of the ecological status does not require the determination of absolute fish densities, but relative species composition and abundance [58]. During electric fish sampling, species composition and relative abundance are likely to be biased because of differences in the catchability of different species and fish sizes [3,11,56], which demands sufficient efficiency of the methods. Based on the difficulty of detecting rare species, random sampling should be conducted in conjunction with targeted sampling of rare species or passive methods such as trapping (see also [55]). Methods such as the Longline fishing showed to be not suitable for fish community characterization in this study.

No historic data is available for the Fan River, however, the increasing anthropogenic pressure and resulting aquatic species decline is indicated by many experts. This highlights the overall value of biological monitoring for aquatic health status 
assessment. More detailed information on biological integrity is urgently needed, especially for monitoring of the future status of these river systems.

\section{References}

1. Angermeier PL, Karr JR (1986) Applying an index of biotic integrity based on stream-fish communities: considerations in sampling and interpretation. N Am J Fish Manag 6:418-429. https://doi.org/10.1577/1548-8659(1986)6\%3c418:AAIOBI\%3e2.0.CO;2

2. Bayerisches Landesamt für Umwelt, LfU (2005) Bewertungsverfahren Makrophyten and Phytobenthos Fließgewässer- und Seen-Bewertung in Deutschland nach EG-WRRL, Informationsheft 1/05. LfU München, Germany

3. Bohlin T, Hamrin S, Heggberget TG, Rasmussen G, Saltveit SJ (1989) Electrofishing-theory and practice with special emphasis on salmonids. Hydrobiologia 173:9-43. https://doi.org/10. 1007/BF00008596

4. Bonar SA, Contreras-Balderas S, Iles AC (2009) Introduction to standardized sampling. In: Bonar SA, Hubert WA, Willis DW (eds) Standard methods for sampling North American freshwater fishes. American Fisheries Society, Bethesda, pp 1-12

5. Brandner J, Pander J, Mueller M, Cerwenka A, Geist J (2013) Effects of sampling techniques on population assessment of invasive round goby. J Fish Biol 82:2063-2079. https://doi.org/ $10.1111 / \mathrm{jfb} .12137$

6. Bund/Länder-Arbeitsgemeinschaft Wasser, LAWA (2011). Überarbeitung der Verfahrensbeschreibung der Gewässerstrukturkartierung in der Bundesrepublik Deutschland. Verfahren für kleine bis mittelgroße Fließgewässer. Berlin, Germany: Kulturbuchverlag $\mathrm{GmbH}$

7. Bund/Länder-Arbeitsgemeinschaft Wasser, LAWA (2014). Klassifizierung des Wasserhaushalts von Einzugsgebieten und Wasserkörpern - Verfahrensempfehlung. a) Handlungsanleitung. https://www.gewaesser-bewertung.de/files/lawa_wh_verfahrensempfehlung.pdf

8. DIN EN ISO 38410-1. German standard methods for the examination of water, waste water and sludge - Biological-ecological analysis of water (group M) - Part 1: Determination of the saprobic index in running waters (M 1)

9. DIN EN ISO 10870. Water quality - Guidelines for the selection of sampling methods and devices for benthic macroinvertebrates in fresh waters (ISO 10870:2012); German version EN ISO 10870:2012

10. CEN EN 140118 (2003) Water quality-sampling of fish with electricity, 18 pp. European Committee for Standardization, Brussels

11. Daulwater DC, Fisher WL (2007) Electrofishing capture probability of smallmouth bass in streams. N Am J Fish Manag 27:162-171. https://doi.org/10.1577/M06-008.1

12. DIN EN ISO 10870 Water quality - Guidelines for the selection of sampling methods and devices for benthic macroinvertebrates in fresh waters (ISO 10870:2012); German version EN ISO 10870:2012

13. Dudgeon D et al (2006) Freshwater biodiversity: importance, threats, status and conservation challenges. Biol Rev 81(2):163-182. https://doi.org/10.1017/S1464793105006950

14. Dußling U (2009) Handbuch zu fiBS-Schriftenreihe des Verbandes Deutscher Fischereiverwaltungsbeamter und Fischereiwissenschaftler e.V., Heft 15. www.gewaesser-bewertung.de/ files/fibs-handbuch_2009.pdf

15. Dußling U, Berg R, Klinger H, Wolter C (2004) Assessing the ecological status of river systems using fish assemblages. Handbuch Angewandte Limnologie 20. Erg.Lfg. 12/04, pp 1-84

16. European Parliament and Council of the European Union (2000) Directive 2000/60/EC of the European Parliament and the Council of 23 October 2000 establishing a framework for Community action in the field of water policy. https://eur-lex.europa.eu/legal-content/EN/TXT/?uri= CELEX:32000L0060 
17. Gao X, Zhang Y, Ding S, Zhao R, Meng W (2015) Response of fish communities to environmental changes in an agriculturally dominated watershed (Liao River Basin) in northeastern China. Ecol Eng 76:130-141. http://dx.doi.org/10.1016/j.ecoleng.2014.04.019

18. GB 5749-2006 Standards for Drinking Water Quality (2006) National Standard of the People's Republic of China. Ministry of Health

19. Geist J (2015) Seven steps towards improving freshwater conservation. Aquat Conserv 25:447453. https://doi.org/10.1002/aqc. 2576

20. German Environment Agency, UBA (2017) Waters in Germany: status and assessment. DessauRoßlau, Germany: UBA. https://www.umweltbundesamt.de/publikationen/waters-in-germany

21. Jähnig SC, Qinghua C (2010) River water quality assessment in selected Yangtze tributaries: background and method development. J Earth Sci 21(6):876-881. https://doi.org/10.1007/s12 583-010-0140-y

22. Jia YT, Sui XY, Chen YF (2013) Development of a fish-based index of biotic integrity for wadeable streams in Southern China. Environ Manag 52:995-1008. https://doi.org/10.1007/ s00267-013-0129-2

23. Johnson RK, Wiederholm T, Rosenberg DM (1993) Freshwater biomonitoring using individual organisms, populations, and species assemblages of benthic macroinvertebrates. In: Rosenberg DM, Resh VH (eds) Freshwater biomonitoring and benthic macroinvertebrates, pp 40-158. Chapman \& Hall, New York

24. Karr JR (1981) Assessment of biotic integrity using fish communities. Fisheries 6:21-27

25. Karr JR, Chu EW (1999) Restoring life in running waters: better biological monitoring. Island Press, Washington

26. Kummu M, De Moel H, Porkka M, Siebert S, Varis O, Ward PJ (2002) Lost food, wasted resources: global food supply chain losses and their impacts on freshwater, cropland, and fertiliser use. Sci Total Environ 438:477-489. https://doi.org/10.1016/j.scitotenv.2012.08.092

27. Lapointe NWR, Corkum LD, Mandrak NE (2006) Point sampling by boat electrofishing: a test of the effort required to assess fish communities. N Am J Fish Manag 26:793-799. https://doi. org/10.1577/M06-007.1

28. Li F, Cai Q, Ye L (2010) Developing a benthic index of biological integrity and some relationships to environmental factors in subtropical Xiangxi river. China. Int Rev Hydrobiol 95(2):171-189. https://doi.org/10.1002/iroh.200911212

29. Li T, Huang X, Jiang X, Wang X (2018) Assessment of ecosystem health of the Yellow River with fish index of biotic integrity. Hydrobiologia 814:31-43. https://doi.org/10.1007/s10750$015-2541-5$

30. Li G-Y (2004) Keeping healthy life of the yellow river - an ultimate aim of taming the Yellow river. Yellow River 26:1-3

31. Liess M, Von der Ohe PC (2005) Analyzing effects of pesticides on invertebrate communities in streams. Environ Toxicol Chem 24:954-965. https://doi.org/10.1897/03-652.1

32. Liu K, Zhou W, Li FL, Lan JH (2010) A fish-based biotic integrity index selection for rivers in Hechi prefecture, Guangxi and their environmental quality assessment. Dongwuxue Yanjiu 31(5):531-538. https://doi.org/10.3724/SP.J.1141.2010.05531

33. Liu MD, Chen DQ, Duan XB, Wang K, Liu SP (2009) Assessment of ecosystem health of Upper and Middle Yangtze river using fish-index of biotic integrity. J Yangtze River Sci Res Inst 27(2): 1-6

34. Lynch PL, Mensinger AF (2011). Seasonal abundance and movement of the invasive round goby (Neogobius melanostomus) on rocky substrate in the Duluth-Superior Harbor of Lake Superior. Ecol Freshw Fish 21:64-74. https://doi.org/10.1111/j.1600-0633.2011.00524.x

35. Maloney EM (2019) How do we take the pulse of an aquatic ecosystem? Current and historical approaches to measuring ecosystem integrity. Environ Toxicol Chem 38(2):289-301. https:// doi.org/10.1002/etc. 4308

36. McRae L, Deinet S, Freeman R (2017) The diversity-weighted living planet index: controlling for taxonomic bias in a global biodiversity indicator. PLoS ONE 12:1-21. https://doi.org/10. 1371/journal.pone.0169156 
37. Meier C, Haase P, Rolauffs P, Schindehütte K, Schöll F, Sundermann A, Hering D (2006) Methodisches Handbuch Fließgewässerbewertung-Handbuch zur Untersuchung und Bewertung von Fließgewässern auf der Basis des Makrozoobenthos vor dem Hintergrund der EG-Wasserrahmenrichtlinie. Methodical stream assessment manual on the basis of the macrozoobenthos and with regards to the European water frame directive

38. Ministry of Ecology and Environment of the People's Republic of China, MEP (2018) 2017 report on the state of the ecology and environment in China. http://english.mee.gov.cn/Resour ces/Reports/soe/

39. Ministry of Environmental Protection of the People's Republic of China, MEP (2002) Environmental quality standards for surface water (GB3838-2002). https://www.chinesestandard. net/PDF/English.aspx/GB3838-2002

40. Mischke U, Behrendt H (2007) Handbuch zum Bewertungsverfahren von Fließgewässern mittels Phytoplankton zur Umsetzung der EU-WRRL in Deutschland. Schweizerbart, Stuttgart

41. Mueller M, Pander J, Knott J, Geist J (2017) Comparison of nine different methods to assess fish communities in lentic flood-plain habitats. J Fish Biol 91:144-174. https://doi.org/10.1111/ jfb. 13333

42. National People's Congress, NPC (2016). The 13th Five Five-Year-Plan for the Economic and Social Development of the People's Republic of China 2016-2020. Beijing, China: Central Compilation \& Translation Press

43. Palmer MA, Febria CM (2012) The heartbeat of ecosystems. Science 336:1393-1394. https:// doi.org/10.1126/science. 1223250

44. Pan B et al (2013) An exploratory analysis of benthic macroinvertebrates as indicators of the ecological status of the Upper Yellow and Yangtze Rivers. J Geogr Sci 23(5):871-882. https:// doi.org/10.1007/s11442-013-1050-6

45. Pander J, Geist J (2013) Ecological indicators for stream restoration success. Ecol Indic 30:106118. https://doi.org/10.1016/j.ecolind.2013.01.039

46. Pander J, Mueller M, Knott J, Geist J (2018) Catch-related fish injury and catch efficiency of stow-net-based fish recovery installations for fish-monitoring at hydropower plants. Fish Manag Ecol 25:31-43. https://doi.org/10.1111/fme.12263

47. Pantle R, Buck H (1955) Die Biologische Überwachung der Gewässer und die Darstellung der Ergebnisse. Besondere Mitteilungen zum Gewässerkundlichen Jahrbuch 12:159-162

48. Pei XJ, Niu CJ, Gao X, Xu C (2010) The ecological health assessment of Liao River Basin, China, based on biotic integrity index of fish. Shengtai Xuebao/Acta Ecologica Sinica 30(21):5736-5746

49. Persat H, Copp GH (1990) Electric fishing and point abundance sampling for the ichthyology of large rivers. In: Cowx IG (ed) Developments in Electric Fishing. Kluwer, Amsterdam, pp 197-209

50. Pignata $C$ et al (2013) Application of European Biomonitoring techniques in China: are they a useful tool? Ecol Indic 29:489-500. https://doi.org/10.1016/j.ecolind.2013.01.024

51. Pottgiesser T, Sommerhäuser M (2008) Beschreibung und Bewertung der deutschen Fließgewässertypen-Steckbriefe und Anhang. https://gewaesser-bewertung.de/files/steckb riefe_anhang_april2008.pdf

52. Rapport DJ, Costanza R, McMichael AJ (1998) Assessing ecosystem health. Trends Ecol Evol 13:397-402. https://doi.org/10.1016/S0169-5347(98)01449-9

53. Schneider S, Melzer A (2003) The trophic index of macrophytes (TIM): a new tool for indicating the trophic state of running waters. Int Rev Hydrobiol 88(1):49-67

54. Simon TP, Sanders RE (1999) Applying an index of biotic integrity based on great river fish communities: considerations in sampling and interpretation. In: Simon TP (ed) Assessment approaches for estimating biological integrity using fish assemblages. Florida, Boca Raton, pp 475-505

55. Smith KL, Jones ML (2005) Watershed-level sampling effort requirements for determining riverine species composition. Can J Fish Aquati Sci 62:1580-1588. https://doi.org/10.1139/ f05-098 
56. Speas DW, Walters CJ, Ward DL, Rogers RS (2004) Effects of intraspecific density and environmental variables on electrofishing catchability of brown and rainbow trout in the Colorado River. N Am J Fish Manag 24:586-596. https://doi.org/10.1577/M02-193.1

57. Van de Weyer K (2015) NRW-Verfahren zur Bewertung von Fließgewässern mit Makrophyten. Fortschreibung und Metrifizierung, LANUV-Arbeitsblatt 30. LANUV, Recklinghausen, Germany

58. Vehanen T, Sutela T, Jounela P, Huusko A, Mäki-Petäys A (2013) Assessing electric fishing sampling effort to estimate stream fish assemblage attributes. Fish Manag Ecol 20:10-20. https://doi.org/10.1111/j.1365-2400.2012.00859.x

59. Vinebrooke RD, Cottingham KL, Norberg J, Scheffer M, Dodson SI, Maberly SC, Sommer $\mathrm{U}$ (2004) Impacts of multiple stressors on biodiversity and ecosystem functioning: the role of species co-tolerance. Oikos 104:451-457. https://doi.org/10.1111/j.0030-1299.2004.13255.x

60. Vitousek PM, Mooney HA, Lubchenco J, Melillo JM (1997) Human domination of earth's ecosystems. Science 277:494-499. https://doi.org/10.1126/science.277.5325.494

61. Vörösmarty CJ et al (2010) Global threats to human water security and river biodiversity. Nature 467:555-561. https://doi.org/10.1038/nature09440

62. Wang L, Gong Z, Zhang J, Li Y (2007) Comprehensive index system for evaluation of river ecosystem health. China Water Wastewater 22(23):97-100

63. Wang Q, Yuan X, Liu H, Xu PX, Wang Z, Zhang Y (2014) Stream Habitat assessment of Dong River, China, using River Habitat survey method. Sheng Tai Xue Bao/Acta Ecologica Sinica 34(6):1548-1558. https://doi.org/10.5846/stxb201210201458

64. Wang Y et al (2014) A national pilot scheme for monitoring of ecological integrity of surface waters in China. Environ Dev 10(1):104-107. https://doi.org/10.1016/j.envdev.2014.02.003

65. Xie YH (2007) Freshwater fishes in Northeast Region of China. Liaoning Science and Technology Press, Shengyang, p 529

66. Xing Y, Zhang C, Fan E, Zhao Y (2015) Freshwater fishes of China: species richness, endemism, threatened species and conservation. Divers Distrib 22(3):358-370. https://doi.org/10.1111/ ddi.12399

67. Yang L-F, Li Y-W, Qi D-G et al. (1992) The assessment of aquatic insect community structure and biological water quality in Jiuhua River. Acta Ecol Sinica 12(1):8-15

68. Young JAM, Marentette JR, Gross C, McDonald JI, Verma A, Marsh-Rollo SE, Macdonald PDM, Earn DJD, Balshine S (2010) Demography and substrate affinity of the round goby (Neogobius melanostomus) in Hamilton Harbour. J Great Lakes Res 36:115-122. https://doi. org/10.1016/j.jglr.2009.11.001

69. Yue Z-M (2005) Maintenance of the Pearl River health life, building a Green Pearl River, and Strive to build a Harmonious society. Pearl River 2:1-5. https://doi.org/10.3969/j.issn.10019235.2005.03.001

70. Zhao Y, Yang Z (2005) Preliminary study on assessment of urban river ecosystem health. Adv Water Sci 16(3):349-355

Open Access This chapter is licensed under the terms of the Creative Commons Attribution 4.0 International License (http://creativecommons.org/licenses/by/4.0/), which permits use, sharing, adaptation, distribution and reproduction in any medium or format, as long as you give appropriate credit to the original author(s) and the source, provide a link to the Creative Commons license and indicate if changes were made.

The images or other third party material in this chapter are included in the chapter's Creative Commons license, unless indicated otherwise in a credit line to the material. If material is not included in the chapter's Creative Commons license and your intended use is not permitted by statutory regulation or exceeds the permitted use, you will need to obtain permission directly from the copyright holder.

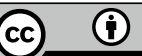

